\title{
Postępy w przeszczepianiu krwiotwórczych komórek macierzystych
}

\author{
Advances in hematopoietic stem cells transplantation
}

\author{
Sebastian Giebel \\ Klinika Transplantacji Szpiku i Onkohematologii, Centrum Onkologii \\ — Instytut im. Marii Skłodowskiej-Curie, Oddział w Gliwicach
}

\begin{abstract}
Streszczenie
W globalnej perspektywie liczba przeszczepień autologicznych (auto) $i$ allogenicznych (allo) krwiotwórczych komórek macierzystych (HSCT) w kolejnych latach sie zwiększa. W 2012 roku wykonano milionowy zabieg na świecie. Nowym wskazaniem do auto-HSCT jest twardzina uktadowa. $W$ randomizowanym badaniu wykazano wyższość takiego leczenia nad obowiazujacym dotad standardem. Najczéściej wykorzystywanym źródtem komórek krwiotwórczych do auto-HSCT i allo-HSCT jest krew obwodowa, jakkolwiek nie ma dowodów na jej wyższość nad szpikiem pod wzgledem catkowitego przeżcia chorych po allo-HSCT. Zwiększa sie liczba allo-HSCT ze zredukowana intensywnościa kondycjonowania, co umożliwia stosowanie transplantacji u chorych $w$ starszym wieku. Opracowano też nowe protokoty mieloablacyjne o zmniejszonej toksyczności. Wobec statego wzrostu liczby zarejestrowanych woluntariuszy dostęność niespokrewnionych dawców komórek krwiotwórczych ulega poprawie. Równolegle zwiększa sie liczba transplantacji od dawców haploidentycznych (haplo-HSCT). Metoda ta stata sie powszechnie dostęna dzięki opracowaniu protokotu immunosupresji obejmujacego podawanie cyklofosfamidu po transplantacji.
\end{abstract}

Słowa kluczowe: transplantacja krwiotwórczych komórek macierzystych, wskazania, kondycjonowanie, dawcy komórek krwiotwórczych

Hematologia 2015; 6, 1: 85-89

\begin{abstract}
Within a global perspective, the number of autologous (auto) and allogeneic (allo) hematopoietic stem cells transplantations (HSCT) is seen to be continuously growing over time. There have been one million such worldwide transplants registered up to 2012. Systemic sclerosis is a new indication for auto-HSCT, and in a randomized trial this method was found superior to the reference standard. Peripheral blood is the most frequently used source of hematopoietic cells for both auto-HSCT and allo-HSCT, although so far there is no evidence of its advantage over bone marrow in terms of overall survival after allogeneic transplant. The number of allo-HSCTs with reduced intensity conditioning is also growing, which can thus be applied to elderly patients. On the other hand, myeloablative protocols with reduced toxicity have been also developed. The availability of unrelated transplants is increasing due to the growing number of registered volunteers. In parallel,
\end{abstract}

Adres do korespondencji: Sebastian Giebel, Klinika Transplantacji Szpiku i Onkohematologii, Centrum Onkologii — Instytut im. Marii Skłodowskiej-Curie, Oddział w Gliwicach, ul. Wyrzeże Armii Krajowej 15, 44-101 Gliwice, tel. 3227885 23, faks 3227891 49, e-mail: sgiebel@io.gliwice.pl 


\section{haploidentical transplants (haplo-HSCT) have become increasingly popular thanks to new immu- nosuppressive protocols that use cyclophosphamide post-transplantation}

Key words: hematopoietic stem cells transplantation, indications, conditioning, stem cells donors

Hematologia 2015; 6, 1: 85-89

\section{Wprowadzenie}

Przeszczepienie krwiotwórczych komórek macierzystych (HSCT, hematopoietic stem cells transplantation) jest uznaną metodą wykorzystywaną w leczeniu wielu nowotworów układów krwiotwórczego i chłonnego, a także niektórych schorzeń nienowotworowych. Umożliwia ona zastosowanie chemioterapii czy radioterapii w dawkach mieloablacyjnych. W przypadku przeszczepień allogenicznych (allo-HSCT, allogeneic HSCT) możliwe jest ponadto wystąpienie efektu przeszczep przeciw nowotworowi - allo-HSCT można zatem uznać za formę immunoterapii.

W 2012 roku wykonano milionową procedure HSCT, co ogłoszono w niedawnej publikacji zbiorczej Światowej Sieci Przeszczepiania Krwi i Szpiku [1]. W raporcie podkreślono dużą dynamikę wzrostu liczby zabiegów w czasie, zarówno w odniesieniu do transplantacji autologicznych (auto-HSCT), jak i allo-HSCT. Prawie połowę spośród wszystkich procedur wykonano w latach 2006-2012. Przyczyną stałego wzrostu aktywności w zakresie HSCT jest poszerzająca się liczba wskazań, zwiększająca się górna granica wieku kwalifikowanych chorych oraz rosnąca dostępność dawców. Zwrócono jednak uwagę na duże różnice aktywności między poszczególnymi regionami. Najwięcej zabiegów wykonano w Europie i obu Amerykach (łącznie 88\%), najmniej natomiast - w Afryce (2\%). Liczba transplantacji $\mathrm{w}$ przeliczeniu na populacje poszczególnych krajów ściśle koreluje $z$ ich statusem socjoekonomicznym [2]. Wykazano tė̇ związek między zamożnością państwa i wynikami leczenia a, w szczególności, śmiertelnością niezwiązaną $z$ nawrotem (NRM, non-relapse mortality). $Z$ jednej strony w krajach o wyjątkowo wysokim wskaźniku rozwoju prawdopodobieństwo przeżycia wolnego od białaczki po allo-HSCT jest większe [2]. $Z$ drugiej strony obserwuje się stałą poprawę wyników transplantacji w kolejnych latach, co jest tłumaczone postępem w zakresie leczenia wspomagającego oraz możliwością lepszego przygotowania chorych do zabiegu poprzez ograniczenie masy nowotworu $z$ zastosowaniem nowych form terapii celowanych [3]. Poprawę wyników odnotowano między innymi w krajach Europy Środkowo-Wschodniej, do których należy Polska [4].

\section{Wskazania do HSCT}

Kwalifikacja chorego i wybór rodzaju HSCT zależą od rozpoznania i stadium choroby, a także wieku i stanu biologicznego. Profil najczęstszych wskazań nie zmienił się istotnie w ostatniej dekadzie. Według danych Europejskiej Grupy ds. Leczenia Krwi i Szpiku (EBMT, European Group for Blood and Marrow Transplantation) allo-HSCT wykonuje się głównie u chorych na ostre białaczki (51\%), a w dalszej kolejności - na nowotwory układu chłonnego (18\%), zespoły mielodysplastyczne (12\%) i wrodzone lub nabyte zespoły niewydolności szpiku (11\%) [5]. Najczęstszymi wskazaniami do auto-HSCT są szpiczak plazmocytowy (48\%), chłoniak Hodgkina i chłoniaki nie-Hodgkina (40\%) oraz nowotwory lite $(7 \%)$.

Oprócz wskazań o ustalonym znaczeniu istnieje wiele chorób, w których zastosowanie HSCT jest opcją kliniczną, a decyzja o kwalifikacji ma charakter zindywidualizowany. Do takich wskazań należą choroby autoimmunizacyjne, w tym choroby układowe tkanki łącznej. W tych przypadkach można rozważyć auto-HSCT z przygotowaniem ukierunkowanym na immunoablację.

Współcześnie trudno jest zorganizować i przeprowadzić badania kliniczne, które pozwoliłyby na jednoznaczne zdefiniowanie nowych wskazań do HSCT. W ostatnich 5 latach opublikowano wyniki tylko jednego takiego badania (ASTIS), dotyczącego chorych na twardzinę układową (SSc, systemic sclerosis); przeprowadzono je w ramach EBMT [6]. Randomizacji poddano 156 pacjentów $z$ rozległymi zmianami skórnymi i towarzyszącym zajęciem płuc, serca lub nerek. Czas trwania SSc wynosił maksymalnie 4 lata. $\mathrm{W}$ grupie referencyjnej stosowano cyklofosfamid (Cy) w pulsach po $750 \mathrm{mg} / \mathrm{m}^{2}$ podawanych $\mathrm{w}$ miesięcznych odstępach przez rok. Chorzy w grupie eksperymentalnej otrzymywali $\mathrm{Cy}$ $\mathrm{w}$ dawce $4 \mathrm{~g} / \mathrm{m}^{2} \mathrm{w}$ skojarzeniu $\mathrm{z}$ filgrastymem jako mobilizację komórek krwiotwórczych. Materiał przeszczepowy poddawano pozytywnej selekcji komórek CD34+. Kondycjonowanie obejmowało Cy w dawce $200 \mathrm{mg} / \mathrm{kg} \mathrm{mc}$. oraz globulinę antytymo- 
cytarną. W grupie poddawanej HSCT obserwowano znamiennie większą poprawę $\mathrm{w}$ zakresie zmian skórnych oraz parametrów czynnościowych pluc, jak również jakości życia. Stwierdzono też niższe ryzyko wystąpienia zdarzeń definiowanych jako zgon lub wystąpienie ciężkiej, trwałej niewydolności serca, płuc lub nerek (współczynnik ryzyka, HR [hazard ratio $]=0,34 ; 95$-proc. przedział ufności [CI, confidence interval]: 0,16-0,74; $\mathrm{p}=0,006)$. Mimo większej śmiertelności zależnej od procedury, w obserwacji 4-letniej zastosowanie HSCT wiązało się z niższym łącznym ryzykiem zgonu $(\mathrm{HR}=0,29,95 \%$ CI: 0,13-0,64; $\mathrm{p}=0,002)$. Wykazanie wpływu na przeżycie definiuje auto-HSCT jako nowy standard leczenia $u$ chorych $z$ zaawansowaną postacią SSc. Autorzy podkreślają jednak konieczność właściwej kwalifikacji chorych oraz odpowiedniego leczenia wspomagającego w celu uniknięcia zagrażających życiu powikłań.

\section{Źródła komórek krwiotwórczych}

Źródłem komórek krwiotwórczych do HSCT mogą być być szpik kostny, krew obwodowa lub krew pępowinowa. W przypadku auto-HSCT przeszczepienia komórek $z$ krwi obwodowej, cechujące się krótszym czasem regeneracji hematopoezy, zaczęły przeważać już w latach 90 . XX wieku; obecnie stanowią ponad $99 \%$ procedur [5]. Podobną tendencję obserwuje się $\mathrm{w}$ odniesieniu do allo-HSCT; według danych $z$ rejestru EBMT dotyczących 2013 roku krew obwodowa jest tu wykorzystywana w $74 \%$ przypadków. Należy jednak podkreślić, że - jak dotąd - brakuje dowodów wskazujących na przewagę krwi obwodowej nad szpikiem w odniesieniu do przé̇ycia po allo-HSCT. Co więcej, w kilku badaniach wykazano, że transplantacje $z$ krwi obwodowej $\mathrm{w}$ przypadku dawców rodzinnych wiążą się $z$ wyższym ryzykiem wystąpienia przewlekłej choroby przeszczep przeciw gospodarzowi (GvHD, graft versus host disease) [7]. W 2012 roku opublikowano odległe wyniki jednego $z$ badań, prowadzonego $\mathrm{w}$ latach 1996-1999 w trzech ośrodkach amerykańskich [8]. W grupie 172 poddanych randomizacji pacjentów $z$ nowotworami układów krwiotwórczego i chłonnego dowiedziono, że prawdopodobieństwo przeżycia wolnego od choroby po 10 latach było znamiennie większe dla HSCT $z$ wykorzystaniem krwi obwodowej, co wynikało $\mathrm{z}$ mniejszego prawdopodobieństwa nawrotu (20\% v. 32\%; $\mathrm{p}=0,01)$. Stwierdzono też tendencję do dłuższego przeżycia $(\mathrm{p}=0,2)$ przy braku różnic w odniesieniu do występowania przewlekłej GvHD.
W tym samym roku opublikowano wyniki jedynego, jak dotąd, badania służącego prospektywnemu porównaniu obu źródeł komórek krwiotwórczych w odniesieniu do transplantacji od dawców niespokrewnionych [9]. Randomizacją objęto 551 chorych leczonych w 48 ośrodkach amerykańskich. Prawdopodobieństwo przeżycia po 2 latach nie różniło się znamiennie i wyniosło $51 \%$ dla krwi obwodowej i $46 \%$ dla szpiku; brak wszczepu stwierdzono odpowiednio u 3\% i $9 \%$ chorych $(\mathrm{p}=0,002)$. Nie wykazano różnic $\mathrm{w}$ odniesieniu do występowania ostrej GvHD, natomiast prawdopodobieństwo wystąpienia przewlekłej GvHD było znamiennie większe po transplantacjach $\mathrm{z}$ użyciem krwi obwodowej ( $53 \%$ v. 41\%; $\mathrm{p}=0,01)$.

Ryzyko wystąpienia przewlekłej GvHD może być zmniejszone poprzez zastosowanie globuliny antytymocytarnej $\mathrm{w}$ ramach przygotowania do allo-HSCT $z$ krwi obwodowej. Uważa się, że przy odpowiednio dobranych dawkach nie powinno to mieć negatywnego wpływu na występowanie nawrotów białaczki [10].

\section{Kondycjonowanie}

Jedną z głównych przyczyn stale zwiększającej się liczby allo-HSCT jest coraz częstsze stosowanie kondycjonowania o zredukowanej intensywności (RIC, reduced-intensity conditioning), co umożliwia leczenie chorych w starszym wieku i z obecnością schorzeń wspólistniejących. Według danych EBMT, RIC-allo-HSCT stanowily w 2013 roku 40\% wszystkich procedur, co oznaczało wzrost o $11 \%$ w porównaniu z rokiem poprzedzającym [5]. Należy jednak zaznaczyć, że pojęciem RIC obejmuje się bardzo szeroki wybór protokołów, tj. różne zestawy cytostatyków i różne dawki napromieniania całego ciała (TBI, total body irradiation). Różnią się one intensywnością tj. siłą działania przeciwnowotworowego i mielosupresyjnego. Mniejsza intensywność może oznaczać niższe ryzyko śmiertelności związanej z procedurą, ale i większe prawdopodobieństwo nawrotu nowotworu. Dlatego trwają prace na protokołami kondycjonowania, które przy zachowanym potencjale mieloablacyjnym charakteryzowałyby się małą toksycznością.

Tradycyjne protokoły przygotowania mieloablacyjnego obejmowały stosowanie dostnej postaci busulfanu $(\mathrm{Bu}) \mathrm{w}$ skojarzeniu $\mathrm{z} \mathrm{Cy}-$ protokół $\mathrm{Bu} / \mathrm{Cy}$ - lub TBI z Cy (protokół TBI/Cy). Współcześnie Bu jest stosowany głównie w postaci dożylnej (ivBu), która cechuje się znacznie bardziej przewidywalną farmakokinetyką. W analizie retrospektywnej EBMT wyniki leczenia chorych 
na ostrą białaczkę szpikową w całkowitej remisji (CR) za pomocą ivBuCy i TBI/Cy były porównywalne, a w analizie amerykańskiej stwierdzono nawet przewage ivBuCy $\mathrm{w}$ odniesieniu do przeżycia [11,12]. Alternatywą dla Bu może być treosulfan, choć dotąd nie opublikowano wyników badań, w których porównano by prospektywnie ivBu i treosulfan; wyniki badań II fazy, zwłaszcza u chorych na zespoły mielodysplastyczne, są zachęcające [13].

Stosowanie TBI było przedmiotem randomizowanego badania przeprowadzonego w ośrodkach niemieckich. Porównywano w nim klasyczny protokół z wykorzystaniem TBI (12 Gy) i Cy (120 mg/kg mc.) z leczeniem o mniejszej intensywności, tj. TBI (8 Gy) w skojarzeniu $z$ fludarabiną (w łącznej dawce $150 \mathrm{mg} / \mathrm{m}^{2}$ ) [14]. W grupie 195 chorych na ostrą białaczkę szpikową w pierwszej CR w wieku 18-60 lat nie stwierdzono znamiennych różnic w zakresie częstości nawrotów i śmiertelności niezwiązanej $z$ nawrotem. Prawdopodobieństwo całkowitego przeżycia po 3 latach wyniosło $61 \%$ $\mathrm{w}$ grupie leczonej TBI/fludarabiną wobec 58\% w grupie leczonej TBI/Cy. Wykazano przy tym mniejszą częstość występowania ciężkiej postaci zapalenia śluzówek jamy ustnej u chorych leczonych według mniej intensywnego protokołu. Wyniki tego badania wskazują na możliwość zastąpienia Cy fludarabiną oraz zmniejszenia dawki TBI bez negatywnego wpływu na skuteczność leczenia.

\section{Rodzaj dawcy}

Za optymalnego dawcę do allo-HSCT uważa się zgodne w układzie ludzkich antygenów leukocytarnych (HLA, human leukocyte antigen) rodzeństwo. W przypadku jego braku poszukuje się zgodnego dawcy niespokrewnionego (URD, unrelated donor). W Europie już w 2007 roku liczba URD-allo-HSCT przekroczyła liczbę transplantacji od rodzeństwa. W 2013 roku transplantacje od dawców niespokrewnionych stanowity $53 \%$ wszystkich allo-HSCT, a od zgodnych w HLA dawców rodzinnych - 38\% [5]. Pozostałe $9 \%$ były to transplantacje od częściowo niezgodnych dawców rodzinnych. Zwiększająca się liczba URD-allo-HSCT jest możliwa dzięki rosnącej dostępności dawców niespokrewnionych. Liczba woluntariuszy na świecie przekroczyła $26 \mathrm{mln}$, a w Polsce -600 tys. Rejestr polski jest jednym $z$ największych na świecie i trzecim w Europie.

$\mathrm{W}$ pełni zgodnego dawcę niespokrewnionego uważa się za najlepszy wybór w przypadku braku zgodnego w układzie HLA rodzeństwa. U około $30 \%$ chorych jego identyfikacja nie jest jednak możliwa. W takiej sytuacji można rozważyć transplantację od dawcy niespokrewnionego $z$ niezgodnością HLA, przeszczepienie jednej lub dwóch jednostek niespokrewnionej krwi pępowinowej lub transplantację od dawcy rodzinnego zgodnego w tylko jednym haplotypie HLA (haplo-HSCT). Ostatnia opcja wydaje się szczególnie atrakcyjna zważywszy na fakt, że prawie każdy pacjent ma takiego dawcę; $z$ założenia mogą być nim dzieci oraz rodzice, a także większość rodzeństwa i znaczna część dalszej rodziny. Zabieg taki można więc przygotować bardzo szybko. Do niedawna w przypadku haplo-HSCT, w celu uniknięcia nadostrej postaci GvHD, stosowano metody inżynierii zmierzające do usunięcia $z$ materiału przeszczepowego limfocytów T. Wiązało się to $z$ dużymi kosztami i wpływało negatywnie na odnowę układu odpornościowego po transplantacji.

W ostatnich latach zaproponowano wiele metod pozwalających na wykonanie haplo-HSCT $z$ uniknięciem deplecji limfocytów T. Najpopularniejszą obecnie strategię - przeszczepienia niemodyfikowanego szpiku - zaproponowała grupa $z$ Baltimore [16]. Strategia ta polega na przeszczepieniu niemodyfikowanego szpiku. Przez pierwsze 2 dni po transplantacji nie stosuje się żadnej immunosupresji, umożliwiając pobudzenie pochodzących od dawcy alloreaktywnych limfocytów T. Stają się one tym samym wrażliwe na Cy (nie uszkadza macierzystych komórek krwiotwórczych; w niewielkim stopniu działa też na spoczynkowe limfocyty), który w łącznej dawce $100 \mathrm{mg} / \mathrm{kg}$ mc. jest stosowany w dniach +3 . i +4 . Dalsza immunosupresja obejmuje mykofenolan mofetilu i takrolimus podawane od dnia +5 . Podawanie Cy po transplantacji (ptCy, post-transplant cyclophosphamide) ogranicza więc ryzyko GvHD, nie wpływając istotnie na regenerację hematopoezy i rekonstytucję immunologiczną.

W oryginalnej pracy Luznik i wsp. [15], w grupie 67 chorych, u których zastosowano przygotowanie niemieloablacyjne, prawdopodobieństwo ostrej GvHD w stopniu III-IV wyniosło 6\%, a śmiertelność niezwiązana $z$ nawrotem po roku $-15 \%$. Od tego czasu różne grupy wprowadziły modyfikacje protokołu. Wykazano, że materiałem do przeszczepienia mogą być komórki $z$ krwi obwodowej, a kondycjonowanie może mieć charakter mieloablacyjny [16, 17]. Raiola i wsp. [17] opublikowali wyniki analizy wskazującej na 68-procentowe prawdopodobieństwo przeżycia wolnego od choroby po 22 miesiącach u chorych poddanych haplo-HSCT $\mathrm{w} \mathrm{CR}$, a 37-procentowe $-\mathrm{u}$ pacjentów $\mathrm{z}$ aktywną chorobą. Szczególnie zachęcające wyniki przedstawiła grupa włoska w odniesieniu do chorych na 
chłoniaka Hodgkina $z$ nawrotem lub opornością po auto-HSCT [18]. W grupie 26 chorych (w tym $65 \% \mathrm{z}$ aktywną chorobą), u których zastosowano przygotowanie niemieloablacyjne, prawdopodbieństwo przeżycia i przeżycia wolnego od progresji po 3 latach wyniosło odpowiednio $77 \%$ i $63 \%$. Ostra GvHD w stopniu II-IV wystąiła u $24 \%$ chorych, a przewlekła GvHD - u 8\% pacjentów.

Uważa się, że wyniki haplo-HSCT $z$ wykorzystaniem ptCy po transplantacji są co najmniej tak dobre, jak w przypadku URD-HSCT od dawcy z pojedynczą niezgodnością w układzie HLA. Liczba haplo-HSCT gwałtownie wzrasta i w 2013 roku była niemal 2 -krotnie większa od liczby allo-HSCT $z$ krwi pępowinowej.

\section{Podsumowanie}

Przeszczepienie krwiotwórczych komórek macierzystych jest coraz częściej stosowaną metodą, a wyniki leczenia $z$ jej zastosowaniem poprawiają się. Nowym wskazaniem do auto-HSCT o udowodnionej $\mathrm{w}$ badaniu klinicznym skuteczności jest twardzina układowa. Krew obwodowa to obecnie najczęściej wykorzystywane źródło komórek krwiotwórczych do przeszczepienia, zarówno w przypadku auto-HSCT, jaki i allo-HSCT. W ostatnich latach opracowano nowe protokoły przygotowania mieloablacyjnego o zmniejszonej toksyczności z zastosowaniem chemioterapii lub TBI. Dostępność dawców allogenicznych jest coraz lepsza i coraz częściej wykonuje się też transplantacje od dawców haploidentycznych. W tym przypadku haplo-HSCT z zastosowaniem ptCy wydaja się co najmniej tak dobre jak przeszczepienia od dawców niespokrewnionych $z$ pojedynczą niezgodnością w układzie HLA.

\section{Piśmiennictwo}

1. Gratwohl A., Pasquini M.C., Aljurf M. i wsp. Hematopoietic stem cells: lessons from the journey to one million transplants. Lancet Haematol. 2015; 2: e91-e100.

2. Giebel S., Labopin M., Ehninger G. i wsp. Association of Human Development Index with rates and outcomes of hematopoietic stem cell transplantation for patients with acute leukemia. Blood 2010; 116: 122-128.

3. Giebel S., Labopin M., Gorin N.C. i wsp. Improving results of autologous stem cell transplantation for Philadelphia-positive acute lymphoblastic leukaemia in the era of tyrosine kinase inhibitors: a report from the Acute Leukaemia Working Party of the European Group for Blood and Marrow Transplantation. Eur. J. Cancer 2014; 50: 411-417.

4. Giebel S., Labopin M., Holowiecki J. i wsp. Outcome of HLA-matched related allogeneic hematopoietic stem cell transplantation for patients with acute leukemia in first complete remission treated in Eastern European centers. Better results in recent years. Ann. Hematol. 2009; 88: 1005-1013.

5. Passweg J.R., Baldomero H., Bader P. i wsp. Hematopoietic SCT in Europe 2013: recent trends in the use of alternative donors showing more haploidentical donors but fewer cord blood transplants. Bone Marrow Transplant. 2015; 50: 476-482.

6. van Laar J.M., Farge D., Sont J.K. i wsp. Autologous hematopoietic stem cell transplantation vs intravenous pulse cyclophosphamide in diffuse cutaneous systemic sclerosis: a randomized clinical trial. JAMA 2014; 311: 2490-2498.

7. Schmitz N., Beksac M., Bacigalupo A. i wsp. Filgrastim-mobilized peripheral blood progenitor cells versus bone marrow transplantation for treating leukemia: 3-year results from the EBMT randomized trial. Haematologica 2005; 90: 643-648.

8. Mielcarek M., Storer B., Martin P.J. i wsp. Long-term outcomes after transplantation of HLA-identical related G-CSF-mobilized peripheral blood mononuclear cells versus bone marrow. Blood 2012; 119: 2675-2678.

9. Anasetti C., Logan B.R., Lee S.J. i wsp. Peripheral-blood stem cells versus bone marrow from unrelated donors. N. Engl. J. Med. 2012; 367: 1487-1496.

10. Bonifazi F., Bandini G., Arpinati M. i wsp. Intensification of GVHD prophylaxis with low-dose ATG-F before allogeneic PBSC transplantationfrom HLA-identical siblings in adult patients with hematological malignancies: results from a retrospective analysis. Bone Marrow Transplant. 2012; 47: 1105-1111.

11. Nagler A., Rocha V., Labopin M. Allogeneic hematopoietic stem-cell transplantation for acute myeloid leukemia in remission: comparison of intravenous busulfan plus cyclophosphamide (Cy) versus totalbody irradiation plus $\mathrm{Cy}$ as conditioning regimen - a report from the acute leukemia working party of the European group for blood and marrow transplantation. J. Clin. Oncol. 2013; 31: 3549-3556.

12. Bredeson C., LeRademacher J., Kato K. i wsp. Prospective cohort study comparing intravenous busulfan to total body irradiation in hematopoietic cell transplantation. Blood 2013; 122: 3871-3878.

13. Ruutu T., Volin L., Beelen D.W. i wsp. Reduced-toxicity conditioning with treosulfan and fludarabine in allogeneic hematopoietic stem cell transplantation for myelodysplastic syndromes: final results of an international prospective phase II trial. Haematologica 2011; 96: 1344-1350.

14. Bornhäuser M., Kienast J., Trenschel R. i wsp. Reduced-intensity conditioning versus standard conditioning before allogeneic haemopoietic cell transplantationin patients with acute myeloid leukaemia in first complete remission: a prospective, open-label randomised phase 3 trial. Lancet Oncol. 2012; 13: 1035-1044.

15. Luznik L., O'Donnell P.V., Symons H.J. i wsp. HLA-haploidentical bone marrow transplantation for hematologic malignancies using nonmyeloablative conditioning and high-dose, posttransplantation cyclophosphamide. Biol. Blood Marrow Transplant. 2008; 14: 641-650.

16. Castagna L., Crocchiolo R., Furst S. i wsp. Bone marrow compared with peripheral blood stem cells for haploidentical transplantation with a nonmyeloablative conditioning regimen and post-transplantation cyclophosphamide. Biol Blood Marrow Transplant. 2014; 20: 724-729.

17. Raiola A.M., Dominietto A., Ghiso A. i wsp. Unmanipulated haploidentical bone marrow transplantation and posttransplantation cyclophosphamide for hematologic malignancies after myeloablative conditioning. Biol. Blood Marrow Transplant. 2013; 19: 117-122.

18. Raiola A., Dominietto A., Varaldo R. Unmanipulated haploidentical BMT following non-myeloablative conditioning and post-transplantation Cy for advanced Hodgkin's lymphoma. Bone Marrow Transplant. 2014; 49: 190-194. 